\title{
Identification of Contaminated Cells with Viruses, Bacteria, or Fungi by Fourier Transform Infrared Microspectroscopy
}

\author{
V. Erukhimovitch, ${ }^{1}$ M. Huleihil, ${ }^{2}$ and M. Huleihel ${ }^{3}$ \\ ${ }^{1}$ Analytical Equipment Unit, Ben-Gurion University of the Negev, Beer-Sheva, Israel \\ ${ }^{2}$ The Arava Institute for Environmental Studies and the Dead Sea Arava Science Center, Israel \\ ${ }^{3}$ Department of Microbiology, Immunology and Genetics, Faculty of Health Sciences, Ben-Gurion University of the Negev, \\ Beer-Sheva, Israel
}

Correspondence should be addressed to M. Huleihel; mahmoudh@bgu.ac.il

Received 2 May 2013; Revised 19 July 2013; Accepted 3 August 2013

Academic Editor: Elina Genina

Copyright ( 2013 V. Erukhimovitch et al. This is an open access article distributed under the Creative Commons Attribution License, which permits unrestricted use, distribution, and reproduction in any medium, provided the original work is properly cited.

\begin{abstract}
Fourier transform infrared microspectroscopy (FTIR-M) can detect small molecular changes in cells and therefore was previously applied for the identification of different biological samples. In the present study, FTIR spectroscopy was used for the identification and discrimination of Vero cells infected with herpes viruses or contaminated with bacteria or fungi in cell culture. Vero cells in culture were infected herpes simplex virus type 1 (HSV-1) or contaminated with E. coli bacteria or Candida albicans fungi and analyzed by FTIR microscopy at $24 \mathrm{~h}$ postinfection/contamination. Specific different spectral changes were observed according to the infecting or contaminating agent. For instance, both pure fungi and cell culture contaminated with this fungi showed specific peaks at $1030 \mathrm{~cm}^{-1}$ and at $1373 \mathrm{~cm}^{-1}$ regions, while pure E. coli and cell culture contaminated with this bacteria showed a specific and unique peak at $1657 \mathrm{~cm}^{-1}$. These results support the potential of developing FTIR microspectroscopy as a simple, reagent free method for identification and discrimination between different tissue infection or contamination with various pathogens.
\end{abstract}

\section{Introduction}

Serious human diseases are caused by different pathogens such as viruses, bacteria, or fungi. In many cases, it is difficult to distinguish between these various infections by routine physician inspection, particularly at early stages of the infection. There are several routine assays for detection of the responsible pathogens of such infections:

(1) growing of the pathogen in culture and trying to identify it by microscopic observations. This assay is not always simple because each pathogen needs different growth conditions and takes relatively long time till getting the results depending on the pathogen (days to weeks). In addition, this assay is highly dependent on the physician qualification [1];

(2) immune assays using specific antibodies [2];

(3) molecular assays using specific primers.
Although these immune and molecular assays are highly specific, they are relatively expensive and not always available for all pathogens. Furthermore, in order to identify the cause of unclear infection, it might be necessary to examine the sample simultaneously by various assays because the conditions and techniques required for examining various pathogens are completely different.

The detection and identification of pathogen infections by spectroscopic techniques is highly promising due to their sensitivity, rapidity, low expenses, and simplicity. Fourier transform infrared (FTIR) microscopy is considered as a powerful tool for chemical analysis because of its ability to provide detailed information on the spatial distribution of chemical composition at the molecular level [3]. Its applications cover different disciplines including material science, forensics, biochemistry, biomedical science, and geochemistry [3-9]. This technique has been also proved to be sensitive for the identification of cancer cells [1,10-13], stem cells [14, 15], virally infected cells [16-19], and microorganisms [20, 21]. 
Cell cultures are advantageous and more convenient for basic research, compared to "real" tissues due to their homogeneity and the ability to control important culture parameters [22, 23]. Thus, infection or contamination of cell cultures with viruses, bacteria, or fungi may be used to represent infected or contaminated tissues with these pathogens.

In the present study, we either infected Vero cells in culture with herpes simplex virus (HSV-1) or contaminated them with $E$. coli bacteria or Candida albicans fungi. All cell cultures were examined by light microscopy and by FTIRmicroscopy technique trying to detect specific biomarkers for discrimination between the different pathogens at $24 \mathrm{~h}$ after the cells infection or contamination. The results showed significant spectral biomarkers which may be useful for detection or identification of different pathogens involved in tissue infection.

\section{Experiments}

2.1. Cells and Pathogens. African green monkey kidney cells (Vero cells) were grown at $37^{\circ} \mathrm{C}$ in RPMI medium supplemented with $10 \%$ new born calf serum (NBCS) and the antibiotics penicillin, streptomycin, and neomycin.

HSV-1 was obtained from the American Type Culture Collection (ATCC), Rockville, MD, USA. Stock of this virus with high titer was made and stored at $-20^{\circ} \mathrm{C}$. This stock was used for infecting the Vero cells.

E. coli bacteria and Candida albicans fungi were obtained from the microbiology department in our institute.

\subsection{Cell Infection and Contamination}

(1) Cell infection with HSV-1: monolayers of Vero cells grown in $9 \mathrm{~cm}^{2}$ tissue culture plates were incubated at $37^{\circ} \mathrm{C}$ for $2 \mathrm{~h}$ with 1 multiplicity of infection (m.o.i.) of HSV-1 in RPMI medium containing $2 \%$ of NBCS. The unabsorbed virus particles were removed, fresh medium containing $2 \%$ NBCS was added, and the monolayers were incubated at $37^{\circ} \mathrm{C}$. At $24 \mathrm{~h}$ postinfection (p.i.) the cells were examined as follows:

(a) for the appearance of the cytopathic effect (CPE), defined as areas of complete destruction of cells or of morphologically modified cells in the inspected fields, using a light inverted microscope;

(b) by FTIR microscopy.

(2) Cell contamination with bacteria and fungi: about $10^{6}$ of E. coli cells or high amount of Candida albicans were added to monolayers of Vero cells grown in $9 \mathrm{~cm}^{2}$ tissue culture plates and incubated for $24 \mathrm{~h}$ at $37^{\circ} \mathrm{C}$. Then the cell culture was examined by light inverted microscope and by FTIR microscopy.

2.3. Sample Preparation for FTIR Microscopy. Normal cells, infected cells with HSV-1 or contaminated with either $E$. coli or fungi were picked up from the tissue culture. The cells were pelleted by centrifugation at $2000 \mathrm{rpm}$ for $5 \mathrm{~min}$.
Each pellet was washed twice with saline and resuspended in $100 \mu \mathrm{L}$ of saline. The number of cells was counted with hematocytometer, and all tested samples were pelted again and resuspended in an appropriate volume of saline to give a concentration of 1000 cells $/ \mu \mathrm{L}$. A drop of $1 \mu \mathrm{L}$ of each sample was placed on the zinc selenide crystal, air dried, and examined by FTIR microscopy. The radius of such $1 \mu \mathrm{L}$ drop was about $1 \mathrm{~mm}$.

2.4. FTIR Spectra Measurement. FTIR measurements were performed in the transmission mode with a liquid-nitrogencooled MCT detector of the FTIR microscope (Bruker IRscope II) coupled to an FTIR spectrometer (BRUKER EQUINOX model 55/S, OPUS software). The spectra were obtained in the wavenumber range of $4000-800 \mathrm{~cm}^{-1}$. Spectral resolution was set at $4 \mathrm{~cm}^{-1}$. The spectra taken were an average of 128 scans to increase the signal-to-noise ratio. Rubber band baseline correction and vector normalization were applied for all the spectra by OPUS software [24]. Since the samples to be analyzed were sometimes heterogeneous, due to different thickness of the obtained cell layer at various regions over the prepared sample and due to possible presence of high amounts of salts particularly in areas with lower density of cells, appropriate regions were chosen by FTIR microscopy. The aperture used in this study was $100 \mu \mathrm{m}$ (area $7.8 \times 10^{-3} \mathrm{~mm}^{2}$ ), since this aperture gave the best signal/noise ratio. Each experiment with each sample was repeated five times.

\section{Results and Discussion}

3.1. FTIR Spectra of Normal Vero Cells, Pure Bacteria, and Pure Fungi. As a first step in the present study we measured and compared the FTIR spectra of normal Vero cells, purified E. coli, and purified Candida albicans trying to identify significant spectral differences between them which might be used for the identification and the detection of the infecting or the contaminating pathogen in case of cell infection or contamination. The results presented in Figure 1(a) show a typical spectrum for each of the tested objects, although in general the FTIR spectra of the different tested objects are quite similar. The spectra are dominated by the absorbance bands at $1643 \mathrm{~cm}^{-1}$ and $1544 \mathrm{~cm}^{-1}$, that is, the amide I and II bands, respectively. The amide I band arises from $\mathrm{C}=\mathrm{O}$ hydrogen bonded stretching vibrations, and the amide IIfrom $\mathrm{C}-\mathrm{N}$ stretching and $\mathrm{CNH}$ bending vibrations [25]. Amid III band at $1270 \mathrm{~cm}^{-1}$ is contributed by proteins arising from coupling of $\mathrm{C}-\mathrm{N}$ stretching and $\mathrm{N}-\mathrm{H}$ bending [26]. The bands at $900-1300 \mathrm{~cm}^{-1}$ were assigned to $\mathrm{C}-\mathrm{O}$ bending modes of saccharides (glucose, lactose, and glycerol), the peaks at $1360-1430 \mathrm{~cm}^{-1}$ were attributed to $\mathrm{COO}^{-}$of amino acids, and $1430-1480 \mathrm{~cm}^{-1}$ is attributed to fatty acids, phospholipids, and triglycerides [27, 28].

It can be noted that the absorbance intensity at 900$1200 \mathrm{~cm}^{-1}$ is significantly higher for fungi compared to bacteria and Vero cells. These results reflect the significant differences in the components content and in the composition of the tested objects. It is also worthwhile to mention that while 


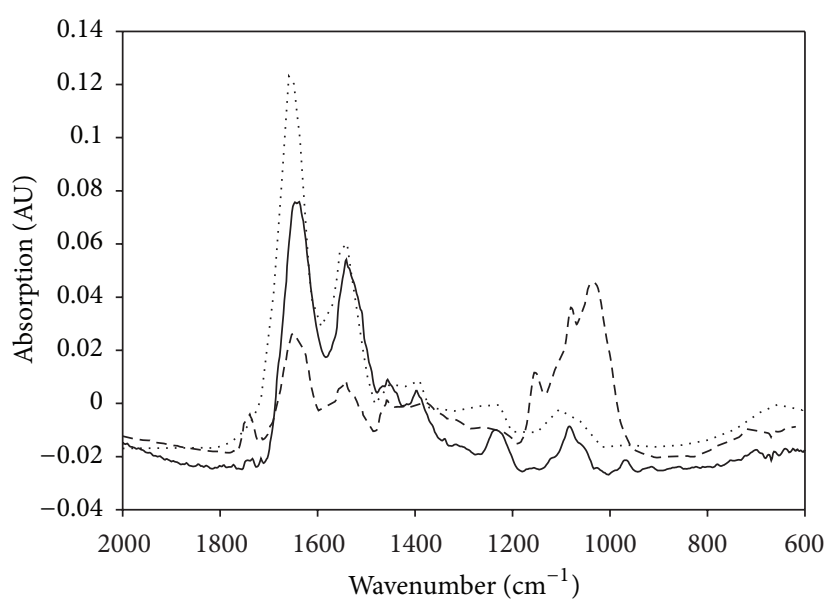

(a)

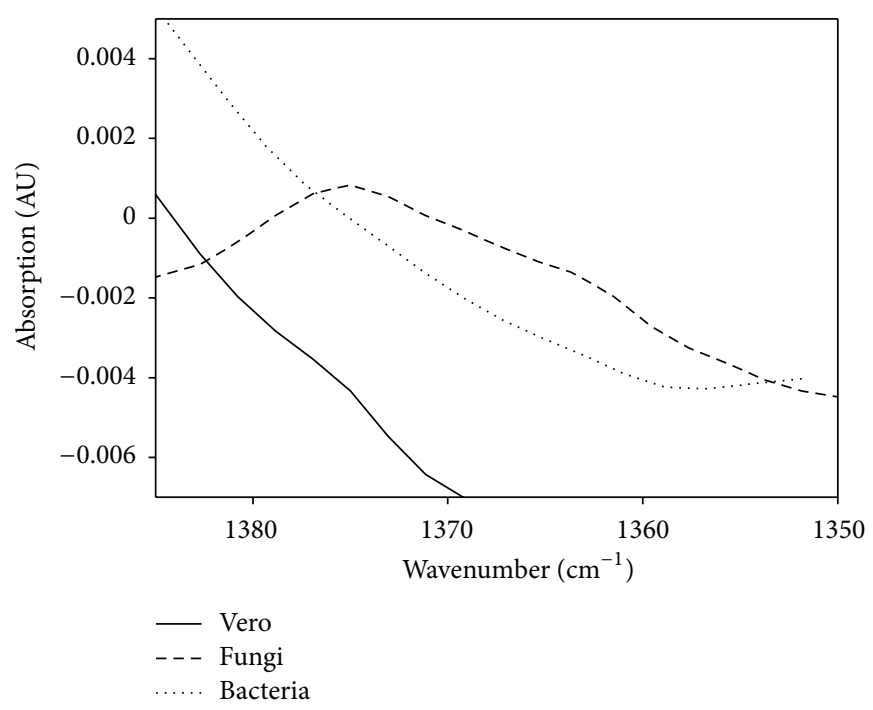

(c)

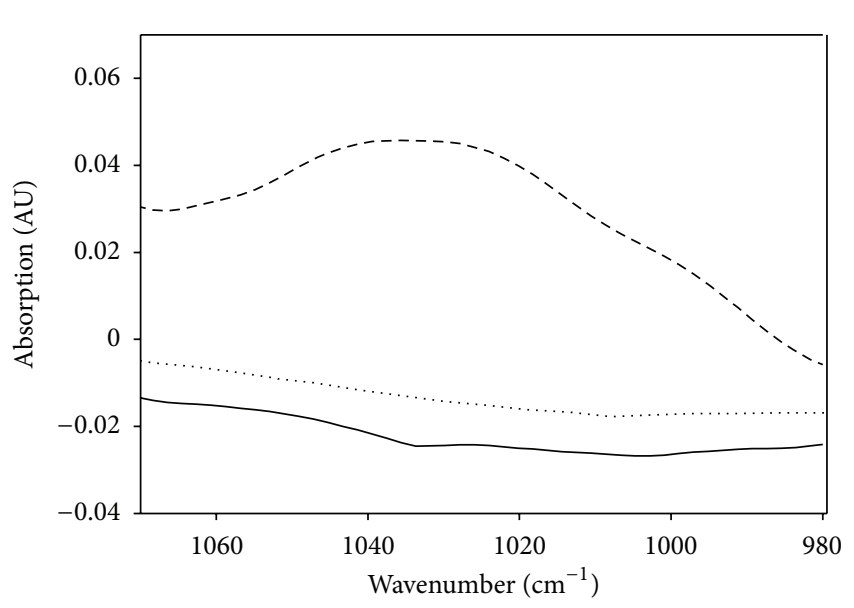

(b)

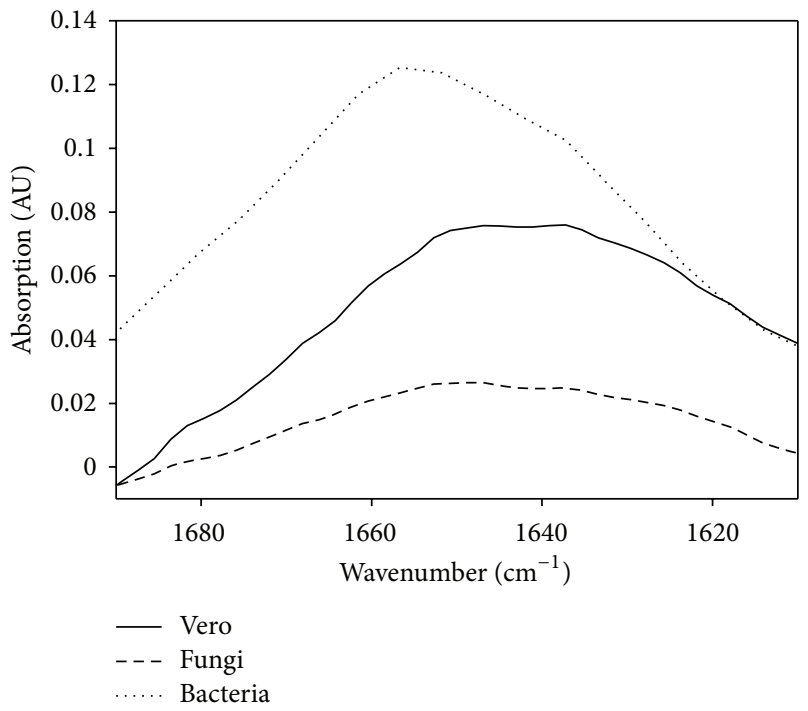

(d)

FIGURE 1: FTIR spectra of control Vero cells, pure E. coli bacteria, and pure Candida albicans fungi at the following regions: (a) $600-2000 \mathrm{~cm}^{-1}$, (b) $1070-980 \mathrm{~cm}^{-1}$, (c) $1390-1350 \mathrm{~cm}^{-1}$, and (d) $1690-1610 \mathrm{~cm}^{-1}$. Data are means of 10 different and separate experiments for each sample.

both bacteria and fungi are growing independently in the growth medium without penetrating into the contaminated cells, viruses are dependent on the host cells for their growth. They penetrate into the host cells, utilize all cellular resources for their advantage, and can cause death of the infected cells such as in the case of the tested virus (HSV-1). be seen.

By focusing on limited spectral regions the following can

(1) At the regions 1050-980 $\mathrm{cm}^{-1}$ (Figure 1(b)) and 1385$1350 \mathrm{~cm}^{-1}$ (Figure $1(\mathrm{c})$ ) there are unique and significant peaks at $1030 \mathrm{~cm}^{-1}$ (Figure 1(b)) and at $1373 \mathrm{~cm}^{-1}$ (Figure 1(c)) belong to fungi sample which are completely missing in Vero and in E. coli samples (Figures 1(b) and 1(c)). These peaks can be attributed to carbohydrates and aliphatic compounds, respectively [26].
(2) At the region $1670-1630 \mathrm{~cm}^{-1}$ both Vero cells and Candida albicans show a unique peak at $1650 \mathrm{~cm}^{-1}$. This peak was significantly shifted into $1657 \mathrm{~cm}^{-1}$ in the case of E. coli (Figure 1(d)). This peak is attributed to protein amid I band [26].

3.2. Spectral Biomarkers or the Identification of Cells Infected with HSV-1 or Contaminated with E. coli or Candida albicans. In the next step Vero cells in culture were infected with HSV1 or contaminated with E. coli or fungi and at $24 \mathrm{~h}$ postinfection or contamination, the cell cultures were examined by FTIR microscopy trying to find specific spectral bands which might be useful for the identification of the infecting or contaminating pathogen.

Our results show significant peaks at 1030 and at $1373 \mathrm{~cm}^{-1}$ in all cell cultures contaminated with fungi (Figures 2 (a) and 2(b), resp.). 


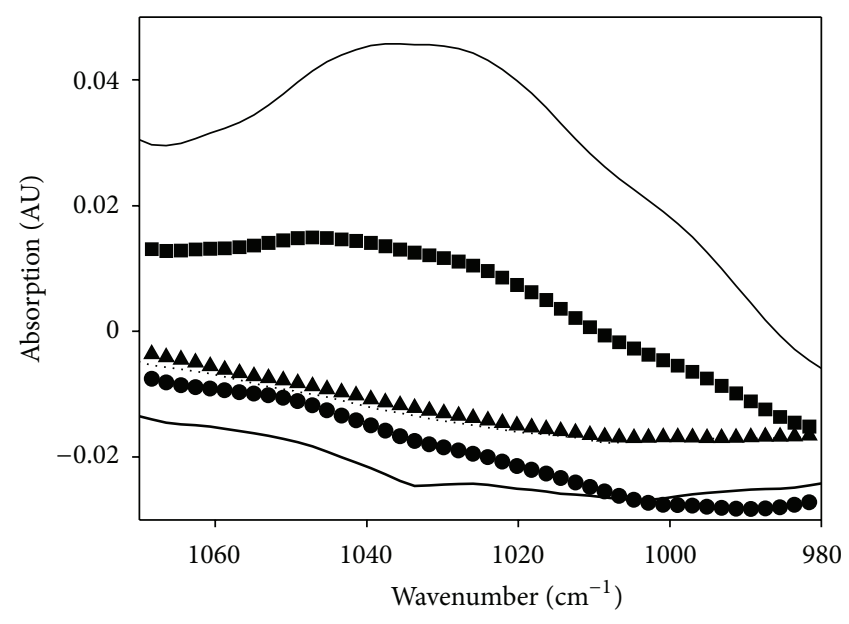

(a)

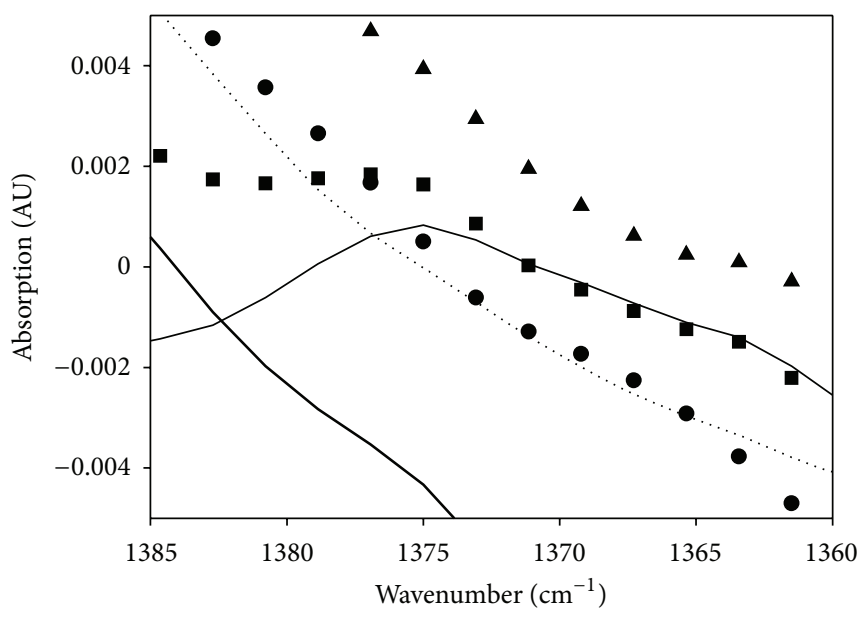

(b)

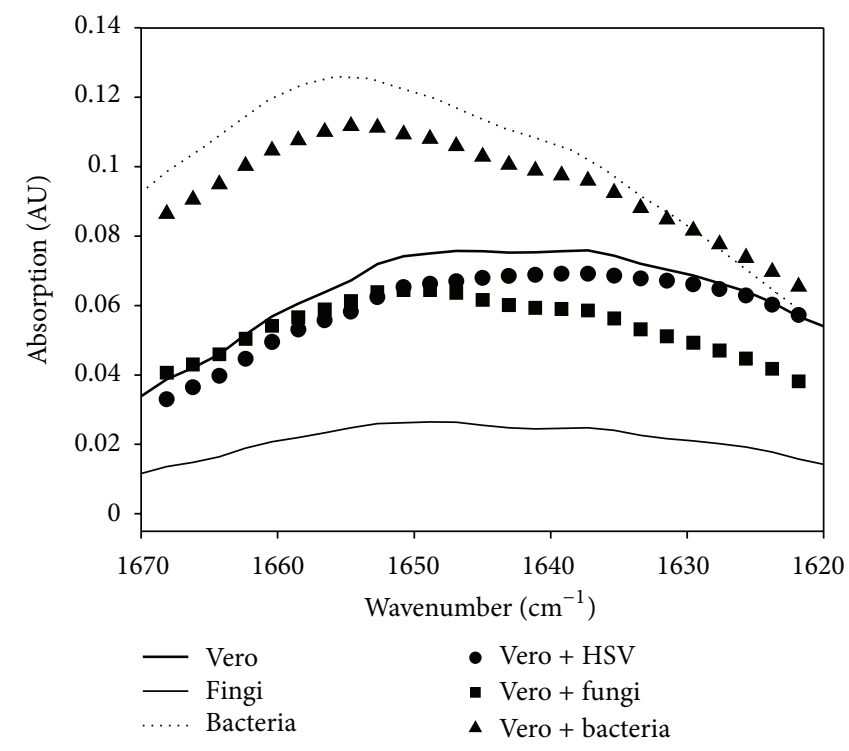

(c)

FIGURE 2: FTIR spectra of control uninfected Vero cells, infected Vero cells with HSV-1, pure E. coli bacteria, Vero cells contaminated with E. coli, pure Candida albicans fungi, and Vero cells contaminated with Candida albicans at the following regions: (a) $1070-980 \mathrm{~cm}^{-1},(\mathrm{~b})$ $1385-1360 \mathrm{~cm}^{-1}$, and (c) $1670-1620 \mathrm{~cm}^{-1}$. Data are means of 10 different and separate experiments for each sample.

These bands, which are typical to fungi as it can be seen in Figure 1, are completely missing in all cell cultures infected with HSV-1 or contaminated with E. coli (Figures 2(a) and 2(b)). However, at the region $1657 \mathrm{~cm}^{-1}$ there is a significant peak only for cell cultures contaminated with $E$. coli (Figure 2(c)). This peak as expected is typical for pure $E$. coli as it was shown in Figure 1(d) and Table 1.

In addition, it can be seen that the peak at $857 \mathrm{~cm}^{-1}$ in normal uninfected cells was significantly shifted into $853 \mathrm{~cm}^{-1}$ in all infected cultures with HSV-1 (Table 1). This spectral peak may be attributed to N-type sugars [29]. This result is in agreement with our previously published results [30]. This peak was not significantly affected as a result of contamination with either E. coli (peak at $856 \mathrm{~cm}^{-1}$ ) or fungi (peak at $857 \mathrm{~cm}^{-1}$ ) (Table 1). Also, both pure E. coli and pure fungi did not show any shift in this peak position (Table 1).
Thus, the results presented in this study show that there are specific spectral biomarkers, for each infection or contamination, which may be useful for reliable identification of the pathogen.

\section{Conclusions}

(1) Our results highlight the potential of FTIR microscopy for detection and identification of spectral changes related to cell culture infection or contamination with different pathogens.

(2) It is possible to differentiate between viral, bacterial, or fungal cell contaminations. Thus, FTIR may offer a promising technique for detection and identification of the pathogen causing tissue infection or inflammation. It is, therefore, worthwhile to continue 
TABLE 1: Changes in peaks position at 857 and $1650 \mathrm{~cm}^{-1}$ as a result of Vero cells infection with HSV-1 or contamination with E. coli or fungi.

\begin{tabular}{lcr}
\hline Sample & \multicolumn{2}{c}{ Wavenumber $\left(\mathrm{cm}^{-1}\right)$} \\
\hline Vero & $1650 \pm 1.2$ & $857 \pm 0.6$ \\
Fungi & $1651 \pm 1.1$ & $858 \pm 1.1$ \\
Bacteria & $\mathbf{1 6 5 7} \pm \mathbf{1 . 6}$ & $857 \pm 0.9$ \\
Vero + bacteria & $\mathbf{1 6 5 6} \pm \mathbf{1 . 8}$ & $856 \pm 0.5$ \\
Vero + fungi & $1651 \pm 2.1$ & $857 \pm 0.8$ \\
Vero + HSV & $1649 \pm 1.2$ & $\mathbf{8 5 3} \pm \mathbf{0 . 5}$ \\
\hline
\end{tabular}

Vero cells were infected with 1 moi of HSV-1 or contaminated with E. coli or fungi. At $24 \mathrm{~h}$ later the different cell cultures were examined by FTIR microscopy. The results are means $\pm \mathrm{SD},(n=5)$.

developing this technique as an efficient and reliable tool for the diagnosis of different pathogens.

(3) Furthermore, for each examination only a small amount of sample $(1-2 \mu \mathrm{L})$ is required and the final results could be obtained during very short time (approximately $1 \mathrm{hr}$ ).

(4) Other viruses, bacteria, and fungi will be evaluated by this technique in the future in order to evaluate the specificity and reliability of this technique.

\section{References}

[1] A. El Bedewi, G. El Anany, M. El Mofty, A. Kretlow, S. Park, and L. M. Miller, "The use of synchrotron infrared microspectroscopy in the assessment of cutaneous T-cell lymphoma vs. pityriasis lichenoides chronica," Photodermatology, Photoimmunology \& Photomedicine, vol. 26, no. 2, pp. 93-97, 2010.

[2] P. Markoulatos, P. Fountoucidou, G. Marinakis et al., "Clear detection and typing of herpes simplex virus types 1 and 2 by an indirect ELISA assay: comparison with three different combined methods-capture ELISA, restriction enzymes, and polymerase chain reaction," Journal of Clinical Laboratory Analysis, vol. 11, no. 3, pp. 146-153, 1997.

[3] H. Mantsch and D. Chapman, Infrared Spectroscopy of Biomolecules, John Wiley, 1996.

[4] M. Diem, S. Boyston-White, and L. Chiriboga, "Infrared spectroscopy of cells and tissues: shining light onto a novel subject," Applied Spectroscopy, vol. 53, no. 4, pp. 148A-161A, 1999.

[5] D. Naumann, D. Helm, and H. Labischinski, "Microbiological characterizations by FT-IR spectroscopy," Nature, vol. 351, no. 6321, pp. 81-82, 1991.

[6] H. Gremlich and B. Yang, Infrared and Raman Spectroscopy of Biological Materials, Marcel Dekker, 2001.

[7] P. Lasch, M. Boese, A. Pacifico, and M. Diem, "FT-IR spectroscopic investigations of single cells on the subcellular level," Vibrational Spectroscopy, vol. 28, no. 1, pp. 147-157, 2002.

[8] S. Argov, R. K. Sahu, E. Bernshtain et al., "Inflamatory bowel diseases as an intermediate stage between normal and cancer: a FTIR-microspectroscopy approach," Biopolymers, vol. 75, no. 5, pp. 384-392, 2004.

[9] T. Nakamura, J. G. Kelly, J. Trevisan et al., "Microspectroscopy of spectral biomarkers associated with human corneal stem cells," Molecular Vision, vol. 16, pp. 359-368, 2010.
[10] V. Erukhimovitch, M. Talyshinsky, Y. Souprun, and M. Huleihel, "Spectroscopic characterization of human and mouse primary cells, cell lines and malignant cells," Photochemistry and Photobiology, vol. 76, no. 4, pp. 446-451, 2002.

[11] E. Gazi, J. Dwyer, N. Lockyer et al., “The combined application of FTIR microspectroscopy and ToF-SIMS imaging in the study of prostate cancer," Faraday Discussions, vol. 126, pp. 41-59, 2004.

[12] E. Njoroge, S. R. Alty, M. R. Gani, and M. Alkatib, in Proceedings of the IEEE Engineering in Medicine \& Biology Society, vol. 1, pp. 5338-5534, 2006.

[13] E. Bogomolny, M. Huleihel, A. Salman, A. Zwielly, R. Moreh, and S. Mordechai, "Attenuated total reflectance spectroscopy: a promising technique for early detection of premalignancy," Analyst, vol. 135, no. 8, pp. 1934-1940, 2010.

[14] C. Petibois, B. Drogat, A. Bikfalvi, G. Déléris, and M. Moenner, "Histological mapping of biochemical changes in solid tumors by FT-IR spectral imaging," FEBS Letters, vol. 581, no. 28, pp. 5469-5474, 2007.

[15] M. J. Walsh, T. G. Fellous, A. Hammiche et al., "Fourier transform infrared microspectroscopy identifies symmetric $\mathrm{PO}_{2}^{-}$ modifications as a marker of the putative stem cell region of human intestinal crypts," Stem Cells, vol. 26, no. 1, pp. 108-118, 2008.

[16] D. E. Maziak, M. T. Do, F. M. Shamji, S. R. Sundaresan, D. G. Perkins, and P. T. T. Wong, "Fourier-transform infrared spectroscopic study of characteristic molecular structure in cancer cells of esophagus: an exploratory study," Cancer Detection and Prevention, vol. 31, no. 3, pp. 244-253, 2007.

[17] A. Salman, V. Erukhimovitch, M. Talyshinsky, M. Huleihil, and M. Huleihel, "FTIR spectroscopic method for detection of cells infected with herpes viruses," Biopolymers, vol. 67, no. 6, pp. 406-412, 2002.

[18] A. E. Bogomolny, M. Huleihel, Y. Suproun, R. K. Sahu, and S. Mordechai, "Early spectral changes of cellular malignant transformation using Fourier transform infrared microspectroscopy," Journal of Biomedical Optics, vol. 12, no. 2, Article ID 024003, 2007.

[19] V. Erukhimovitch, M. Karpasasa, and M. Huleihel, "Spectroscopic detection and identification of infected cells with herpes viruses," Biopolymers, vol. 91, no. 1, pp. 61-67, 2009.

[20] K. Maquelin, C. Kirschner, L.-P. Choo-Smith et al., "Prospective study of the performance of vibrational spectroscopies for rapid identification of bacterial and fungal pathogens recovered from blood cultures," Journal of Clinical Microbiology, vol. 41, no. 1, pp. 324-329, 2003.

[21] C. A. Rebuffo-Scheer, C. Kirschner, M. Staemmler, and D. Naumann, "Rapid species and strain differentiation of non-tubercoulous mycobacteria by Fourier-Transform Infrared microspectroscopy," Journal of Microbiological Methods, vol. 68, no. 2, pp. 282-290, 2007.

[22] A. Tfayli, O. Piot, A. Durlach, P. Bernard, and M. Manfait, "Discriminating nevus and melanoma on paraffin-embedded skin biopsies using FTIR microspectroscopy," Biochimica et Biophysica Acta, vol. 1724, no. 3, pp. 262-269, 2005.

[23] N. S. Eikje, K. Aizawa, and Y. Ozaki, "Vibrational spectroscopy for molecular characterisation and diagnosis of benign, premalignant and malignant skin tumours," Biotechnology Annual Review, vol. 11, pp. 191-225, 2005.

[24] S. Wartewig, IR, and Raman Spectroscopy John Wiley and Sons, New York, NY, USA, 2003. 
[25] D. Yang, D. Castro, I. El-Sayed, M. El-Sayed, R. Saxton, and Y. Nancy, vol. 2389 of Proceedings of SPIE, pp. 543-548, 1995.

[26] R. K. Dukor, "Vibrational spectroscopy in the detection of cancer," in Handbook of Vibrational Spectroscopy, J. M. Chalmers and P. R. Griffiths, Eds., p. 3335, John Wiley and Sons, 2001.

[27] R. J. McNichols and G. L. Coté, "Optical glucose sensing in biological fluids: an overview," Journal of Biomedical Optics, vol. 5, no. 1, pp. 5-16, 2000.

[28] G. Deleris and C. Petibios, "Applications of FT-IR spectrometry to plasma contents analysis and monitoring," Vibrational Spectroscopy, vol. 32, no. 1, pp. 129-134, 2003.

[29] A. E. Taillandier and J. Liguier, in Handbook of Vibrational Spectroscopy, J. M. Chalmers and P. R. Griffiths, Eds., p. 3465, John Wiley and Sons, New York, NY, USA, 2001.

[30] V. Erukhimovitch, M. Talyshinsky, Y. Souprun, and M. Huleihel, "Use of fourier transform infrared microscopy for the evaluation of drug efficiency," Journal of Biomedical Optics, vol. 11, no. 6, Article ID 064009, 2006. 

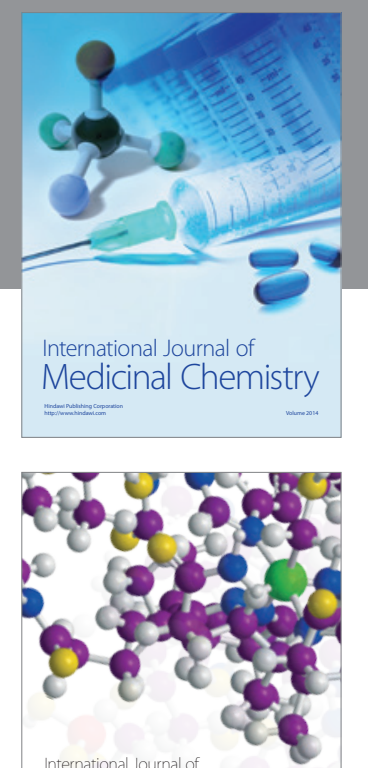

\section{Carbohydrate} Chemistry

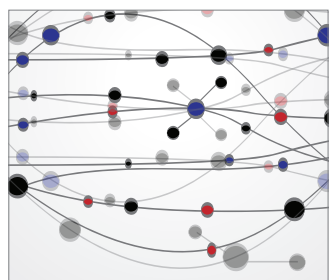

The Scientific World Journal
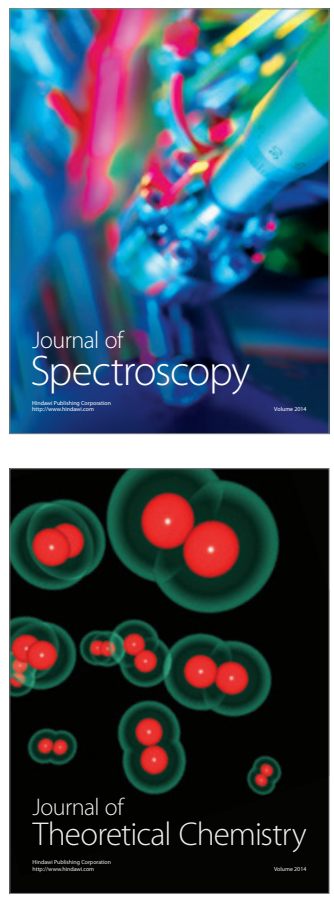
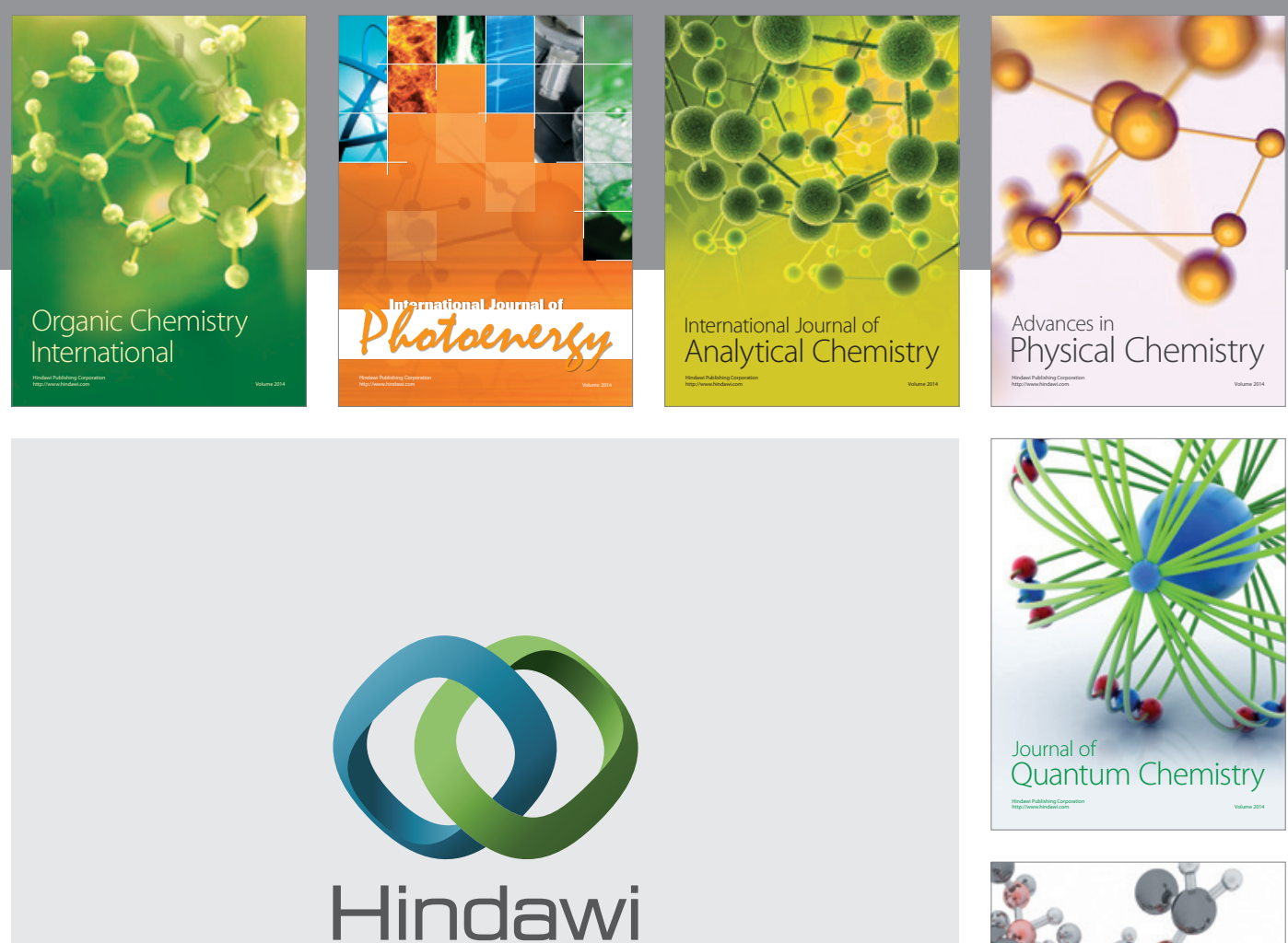

Submit your manuscripts at

http://www.hindawi.com

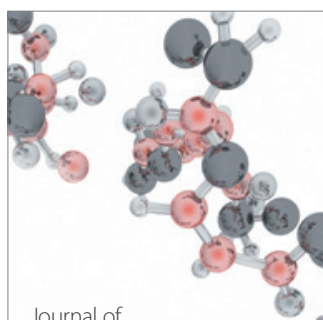

Analytical Methods

in Chemistry

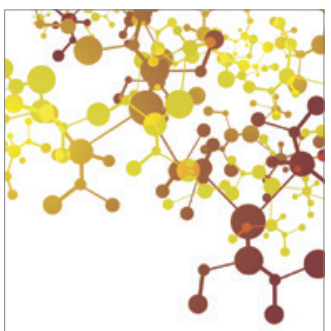

Journal of

Applied Chemistry

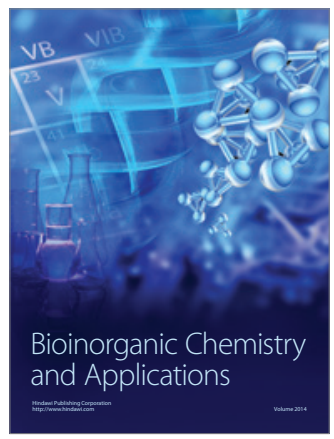

Inorganic Chemistry
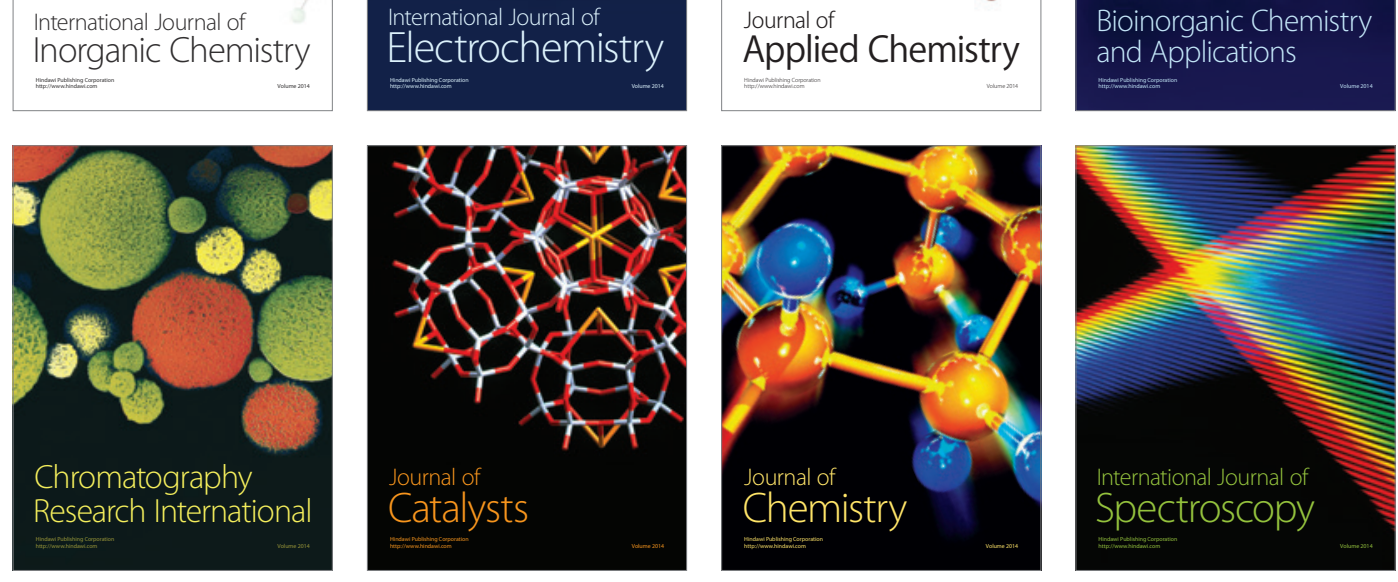